\title{
Hubungan Karakteristik dalam Keluarga dengan Pengetahuan dan Sikap Siswi SMA Uswatun Hasanah Tentang Infeksi Menular Seksual (IMS) di Jakarta Timur
}

\author{
The Association between Characteristics in Family with Knowledge and \\ Attitude of Pupils of Uswatun Hasanah High School about Sexual \\ Transmitted Infection in East Jakarta
}

\section{Alib Birwin}

\section{FIKES UHAMKA, Jakarta}

\begin{abstract}
ABSTRAK
Banyak terjadinya perilaku seks berisiko pada remaja puteri diduga karena pengetahuan yang rendah dan sikap negatif terhadap pendidikan seks yang menyangkut penyakit infeksi manular seksual (IMS); itu berarti bahwa para remaja puteri mempunyai pengetahuan yang rendah dan sikap negatif tentang IMS. Penelitian ini bertujuan untuk mengetahui faktor-faktor yang berhubungan dengan pengetahuan dan sikap siswi SMA Uswatun Hasanah tentang IMS. Metode penelitian menggunakan jenis desain descriptive cross sectional study, populasi adalah siswi SMA Uswatun Hasanah Jakarta Timur tahun 2011 berjumlah 60 orang, sekaligus sebagai sampel dari penelitian ini. Variabel dependen dari penelitian ini adalah pengetahuan dan sikap tentang IMS, yang masing-masig dihubungkan dengan 8 variabel independen. Data primer dikumpulkan melalui wawancara terstruktur menggunakan kuesioner dengan pertanyaan tertutup. Analisis data dilakukan dengan menggunakan analisa univariat dan bivariat dengan menggunakan test kemaknaan $X$ square. Hasil penelitian ini menunjukkan bahwa 1) siswi SMA Uswatun Hasanah yang berpengetahuan rendah dan bersikap negatif terhadap tentang IMS adalah 41,7\% dan $36,7 \%$; 2) umur siswi 15-16 tahun, ibu tidak bekerja, penghasilan orang tua $<\mathrm{Rp} 1,300,000$ dan jumlah anggota keluarga $>3$ orang lebih berisiko mempunyai pengetahuan rendah tentang IMS; 3) Pendidikan bapak SD/SMP, ibu tak bekerja, uang saku harian siswi $<$ Rp. 20,000, penghasilan orang tua $<$ Rp. 1, 300,000 dan jumlah anggota keluarga $>3$ orang lebih berisiko mempunyai sikap negatif tentang IMS; 4) pengetahuan siswi yang rendah tentang IMS berisiko terhadap sikap siswi yang rendah tentang IMS. Direkomendasikan untuk penelitian lebih lanjut menggunakan sampel yang representatif, menghitung besar sampel sesuai dengan jenis disain analytic cross sectional dan melakukan analisis multivariat dan mengetahui efektifitas pendidikan seks dengan perilaku seks berisiko. Disarankan untuk melakukan pendidikan seks kepada siswi SMA Uswatun Hasanah, dan melakukan KIE kepada ibu dan bapak supaya siswi mereka berpengetahuan tinggi dan sikap positif di SMA Uswatun Hasanah Jakarta Timur.
\end{abstract}

Kata kunci: pengetahuan, sikap, karakteristik, pendidikan seks.

\begin{abstract}
It is assumed that many young girls have risky sexual behavior because they have a lack of knowledge and negative attitude on sexual education; it means that the young girls have a lack of knowledge and negative attitude concerning sexual transmitted infection. The objective of this study is to examine several factors associated with knowledge and attitude of pupils of Uswatun Hasanah High School concerning sexual transmitted infection (STI). The method of study uses descriptive cross sectional study, the population and sample of this study is 60 pupils of Uswathun Hasanah High School in 2011. The dependent variables are knowledge and attitude about STI; each of them is associated with 8 independent variables. Collection of primary data was conducted through structural interview by using close ended question. Analysis of data is conducted for one variable and two variables by using $x$ square test. The results of study shows that 1) The pupils of Uswatun Hasanah High School having low knowledge and negative attitude on STI was 41.7\% and 36.7\%; 2) Age of 15-16 years old, mother without occupation, family income $<R$. 1,300,000, and the number of family members $>3$ persons were higher risk to have low knowledge on STI; 3) Father's education of elementary school, family income < 1,300,000 and family member $>3$ persons were higher risk to have negative attitude on STI; and 4) Low knowledge on STI is higher risk to have negative attitude on STI. Recommendation are to conduct further study using representative sample, to calculate sample size for analytic cross sectional study design, to conduct analysis of multi variables, and to detect the effectiveness of sexual education on the risk of sexual behavior. Suggestions are to conduct sexual education to the pupils of, and to conduct communication, information and education to the parents of Uswatun Hasanah High School in East Jakarta.
\end{abstract}

Keywords: knowledge, attitude, characteristics, sexual education 


\section{PENDAHULUAN}

Masa remaja adalah masa peralihan antara masa anak-anak dan masa dewasa, dimana terjadi perubahan fisik dan psikis. Secara fisik, perubahan yang nyata ialah pertumbuhan tulang dan perkembangan alat kelamin serta tanda-tanda seks sekunder, baik laki-laki maupun perempuan. Pada masa remaja dorongan seks meningkat dengan cepat bahkan dorongan itu bisa lebih tinggi dibandingkan dengan orang dewasa. Namun dalam hal mengendalikan diri, remaja masih belum semampu orang dewasa. Selain itu banyak godaan dari luar dirinya seperti teman sebaya, orang dewasa sekitarnya dan ditambah lagi dengan banyaknya media informasi yang bernuansa pornografi yang saat ini tidak dapat dicegah lagi peredarannya. Kondisi demikian memberi dorongan kepada remaja untuk melakukan aktifitas seksual yang tidak terkendali.

Hasil penelitian oleh Resnayati (2000) pada siswa SLTP dan SMUN di Jakarta Timur, dengan sampel 450 siswa, sebanyak $56 \%$ sampel menyatakan punya pacar dan dari jumlah tersebut sebanyak 17,6\% siswa itu melakukan perilaku seks beresiko. Sebuah penelitian yang dilakukan oleh perusahaan riset Internasional Synovate atas nama DKT Indonesia tahun 2005, melakukan penelitian terhadap perilaku seksual remaja berusia 14-24 tahun; penelitian dilakukan terhadap 450 remaja dari Medan, Jakarta, Bandung dan Surabaya. Hasil penelitian tersebut mengungkapkan bahwa 64\% remaja mengakui secara sadar melakukan hubungan seks pranikah. Dari hasil penelitian Oktarina (2007) terlihat bahwa siswa kelas II SMU di kota Depok melakukan hubungan seksual sebanyak 7,4\%, seks bebas yang mengakibatkan kehamilan tidak diinginkan 5,9\%. Sebuah hasil penelitian yang dipublikasikan secara terbatas mengenai perilaku seks remaja ibu kota, menunjukkan berkisar antara 6\% hingga 20\% siswa Sekolah Menengah Umum (SMU) dan mahasiswa di Jakarta pernah melakukan hubungan seks pranikah.

Faktor-faktor yang mempengaruhi perilaku seksual remaja secara umum terdiri dari faktor yang berasal dari dalam diri remaja itu sendiri dan faktor yang berasal dari lingkungan sekitar remaja. Faktor yang berasal dari dalam diri remaja diantaranya adalah pengetahuan dan sikap remaja terhadap seksualitas, sedangkan faktor luar yang mempengaruhi perilaku seksual remaja, terutama adalah keluarga, teman sebaya, dan media massa (Notoatmodjo, 1993).

Akibat kurangnya informasi seks yang benar bagi remaja menyebabkan banyak remaja yang menerima informasi seks yang tidak benar, bahkan menyesatkan, antara lain dari gambar porno, video porno, dan piringan laser (laser disc) porno. Sementara disisi lain, orang tua tidak menjadi sumber informasi yang benar mengenai perkembangan seksualitas remaja. Menurut Gunarsa (1991), salah satu faktor yang mendasari perilaku seks pada remaja adalah kebanyakan orang tua kurang termotivasi memberikan pendidikan seks dan kesehatan reproduksi pada remaja. Ada rasa ketakutan pada orang tua bahwa hal itu justru akan meningkatkan keinginan untuk melakukan hubungan seks sebelum nikah dan membicarakan masalah seks dianggap sebagai langsung atau tidak langsung membangkitkan "macan tidur".

Perkembangan reproduksi remaja terkait erat dengan perkembangan seksualnya. Sebagian remaja tidak mengalami masalah dalam perkembangan seksualnya, tapi tidak sedikit dari mereka karena proses tersebut kehidupan mereka di hari tua menjadi kurang menguntungkan. Saat ini sebagian besar kaum remaja lebih berani mengambil risiko yang mengancam kesehatan reproduksinya, termasuk risiko untuk terjadi infeksi menular seksual (IMS); Tetapi mereka tidak mengetahui banyak informasi mengenai apa itu IMS. Minimnya informasi IMS pada remaja kerap menjadi salah satu persoalan yang membuat mereka salah dalam mengambil keputusan. Informasi IMS pada remaja harus ditingkatkan, agar kelompok kaum muda yang sedang tumbuh berkembang ini dapat memperoleh sumber informasi yang benar. Karena itu, para remaja perlu diberikan dukungan dan perawatan selama masa transisi dari remaja menuju dewasa.

Uraian di atas memberikan gambaran tentang masalah pengetahuan remaja tentang IMS saat ini, karena itu penulis terdorong untuk melakukan penelitian mengenai faktor-faktor yang berhubungan dengan pengetahuan dan sikap siswi SMA Uswatun Hasanah di Jakarta Timur. Tahun 2011.

Permasalahan utama kesehatan reproduksi remaja di Indonesia adalah kurangnya informasi mengenai IMS. Menurut data Kesehatan Reproduksi remaja yang dihimpun Jaringan Epidemiologi Nasional tahun 2002, pemberian informasi IMS yang benar dan bertanggung jawab masih sangat kurang. Pemberian informasi tentang IMS di beberapa tempat masih dipertentangkan, apalagi jika diberi judul pendidikan seksual. Masih terdapat anggapan, pendidikan seksual justru akan merangsang remaja melakukan hubungan seksual. Padahal apabila faktor-faktor yang mempengaruhi pengetahuan dan sikap remaja putri tentang IMS dapat diidentifikasi, maka informasi ini akan sangat berguna bagi program pencegahan dan penanggulangan IMS pada remaja, khususnya kelompok siswi yang remaja putri.

\section{METODE PENELITIAN}

Jenis desain penelitian adalah studi penampang analitik deskriptif. Populasi adalah siswi SMA Uswatun Hasanah berumur 15-19 tahun dengan jumlah 60 orang. Sampel penelitian adalah seluruh populasi. Data dikumpulkan melalui wawancara dengan 
responden yaitu siswi SMA Uswatun Hasanah di Jakarta Timur. Jenis data yang dikumpukan adalah data primer dengan wawancara terstruktur melalui kuesioner. Data dikumpulkan dari variabel dependen yaitu pengetahuan dan sikap; di samping itu dikumpulkan data dari variabel independen yaitu umur, pendidikan bapak, pendidikan ibu, pekerjaan bapak, pekerjaan ibu, uang saku siswi, penghasilan orang tua dan jumlah anggota keluarga. Setelah kuesioner diisi lengkap di lapangan, dilakukan entry data dengan bantuan komputer menggunakan software EPI INFO. Analisis univariat dilakukan untuk melihat distribusi frekuensi dari setiap variabel independent dan variabel dependen, sehingga dapat diketahui variasi dari masing-masing variabel. Analisa bivariat dilakukan untuk melihat kamaknaan hubungan antara variabel independent dan variabel dependen. Uji statistik yang digunakan adalah chi-square, untuk melakukan analisis hubungan antara variabel kategorik dengan variabel kategorik.

\section{HASIL PENELITIAN}

\section{Analisis Univariat}

Tabel 1 menunjukkan bahwa pengetahuan siswi yang rendah tentang IMS adalah $41,73 \%$ dan sikap siswi yang negatif tentang IMS adalah $36,7 \%$.

Tabel 1

Distribusi Pengetahuan dan Sikap Siswi tentang IMS di SMA Uswatun Hasanah Jakarta Timur Tahun 2011

\begin{tabular}{lcc}
\hline \multicolumn{1}{c}{ Variabel } & $\begin{array}{r}\text { Jumlah } \\
\mathbf{N}=\mathbf{6 0}\end{array}$ & Persentase \\
\hline Pengetahuan & 25 & $41,73 \%$ \\
Rendah & 35 & $58,30 \%$ \\
Tinggi & & \\
Sikap & 22 & $36,7 \%$ \\
Negatif & 38 & $63,3 \%$ \\
Positif & & \\
\hline
\end{tabular}

Tabel 2 menunjukkan bahwa terdapat $26,7 \%$ siswi yang berumur $15-16$ tahun, 20,0\% bapak siswi yang bapaknya berpendidikan SD Dan SMP, 31,7\% siswi yang ibunya berpendidikan SD dan SMP, 25\% siswi yng bapaknya bekerja sebagai buruh/pedagang, $45 \%$ siswi yang ibunya tidak bekerja, $20 \%$ siswi yang penghasilan orang tuanya $<$ Rp. $1,300,000$ per bulan, $30 \%$ siswi yang uang sakunya $<$ Rp. 20,000 per hari, dan $56,7 \%$ siswi yang jumlah anggota keluarganya $>3$ orang; tidak terlihat adanya variabel independen yang homogen, dimana salah satu kategorinya $<15 \%$.
Tabel 2

Distribusi Variabel Independen dari Penyakit Infeksi Menular Seksual di SMA Uswatun Hasanah Jakarta Timur Tahun 2011

\begin{tabular}{|c|c|c|}
\hline Variabel Independen & Jumlah & Persentase \\
\hline \multicolumn{3}{|l|}{ Umur Siswi: } \\
\hline $15-16$ tahun & 16 & $26,7 \%$ \\
\hline $17-18$ tahun & 44 & $73,3 \%$ \\
\hline \multicolumn{3}{|l|}{ Pendidikan Bapak: } \\
\hline SD dan SMP & 12 & $20,0 \%$ \\
\hline SMA dan PT & 48 & $80,0 \%$ \\
\hline \multicolumn{3}{|l|}{ Pendidikan Ibu: } \\
\hline SD dan SMP & 19 & $31,7 \%$ \\
\hline SMA dan PT & 41 & $68,3 \%$ \\
\hline \multicolumn{3}{|l|}{ Pekerjaan Bapak } \\
\hline Buruh/Pedagang Pegawai & 15 & $25,0 \%$ \\
\hline Swasta/PNS/Polri/TNI & 45 & $75,0 \%$ \\
\hline \multicolumn{3}{|l|}{ Pekerjaan Ibu } \\
\hline Tidak Bekerja & 27 & $45,0 \%$ \\
\hline Bekerja & 33 & $55,0 \%$ \\
\hline \multicolumn{3}{|l|}{ Penghasilan Orang Tua } \\
\hline$<$ Rp. $1.300 .000 /$ bulan & 20 & $33,3 \%$ \\
\hline$>$ Rp. $1.300 .000 /$ bulan & 40 & $66,7 \%$ \\
\hline \multicolumn{3}{|l|}{ Uang saku siswi: } \\
\hline$<$ Rp. 20.000/hari & 18 & $30,0 \%$ \\
\hline$>$ Rp. 20.000/hari & 42 & $70,0 \%$ \\
\hline \multicolumn{3}{|l|}{ Jumlah anggota keluarga } \\
\hline$>3$ orang & 34 & $56,7 \%$ \\
\hline $1-3$ orang & 26 & $43,3 \%$ \\
\hline
\end{tabular}

\section{Analisis Bivariat}

\section{Hubungan Variabel-variabel Independen dengan Pengetahuan}

Tabel 3 menunjukkan bahwa 1) siswi yang berumur 15-16 tahun lebih berisiko 4,7 kali mempunyai pengetahuan rendah tentang IMS dibandingkan dengan siswi yang berumur $17-18$ tahun(CI 95\%: OR=1,2-19,6);2) siswi yang ibunya tidak bekerja berisiko 2,9 kali mempunyai pengetahuan rendah tentang IMS dibandingkan dengan siswi yang ibunya bekerja (CI 95\%: OR=0,9 - 9,6); 3) siswi yang penghasilan orang tuanya kurang dari 1.300 .000 rupiah perbulan berisiko 3,1 kali mempunyai pengetahuan rendah tentang IMS dibandingkan dengan siswi yang orang tuanya berpenghasilan lebih dari 1.300 .000 rupiah; 4) siswi yang jumlah anggota keluarganya 
lebih dari 3 orang berisiko 8,9 kali mempunyai pengetahuan rendah tentang IMS dibandingkan dengan siswi yang anggota keluarganya $1-3$ orang (CI 95\%; $\mathrm{OR}=2,2-39,3)$.

Tabel 3

Distribusi Hubungan Variabel-variabel Independen dengan Pengetahuan Siswi Tentang Penyakit Infeksi Menular Seksual di SMA Uswatun Hasanah Jakarta Timur Tahun 2011

\begin{tabular}{|c|c|c|c|c|}
\hline \multirow[b]{2}{*}{ Variabel Independen } & \multicolumn{2}{|c|}{$\begin{array}{c}\text { Pengeta } \\
\text { huan }\end{array}$} & \multirow[b]{2}{*}{$\begin{array}{c}\text { OR } \\
(95 \% \text { CI })\end{array}$} & \multirow[b]{2}{*}{$\begin{array}{c}\mathbf{P} \\
\text { value }\end{array}$} \\
\hline & $\begin{array}{c}\text { Re } \\
\text { nda } \\
\text { h }\end{array}$ & $\begin{array}{r}\text { Ti } \\
\text { ng } \\
\text { gi }\end{array}$ & & \\
\hline \multicolumn{5}{|l|}{ Umur siswi } \\
\hline $15-16$ tahun & 11 & 5 & $4,71(1,19$ & 0,010 \\
\hline $17-18$ tahun & 14 & 30 & $-19,59)$ & \\
\hline \multicolumn{5}{|l|}{ Pendidikan Bapak } \\
\hline SD dan SMP & 7 & 5 & $2,33(0,55$ & 0,190 \\
\hline SMA dan PT & 18 & 30 & $-10,21)$ & \\
\hline \multicolumn{5}{|l|}{ Pendidikan Ibu } \\
\hline SD dan SMP & 10 & 9 & $1,93(0,56$ & 0,241 \\
\hline SMA dan PT & 15 & 26 & $-6,71)$ & \\
\hline \multicolumn{5}{|l|}{ Pekerjaan Bapak: } \\
\hline Buruh//pedagang & 9 & 6 & $2,72(0,71$ & 0,096 \\
\hline swasta/PNS/Polri/TNI & 16 & 29 & $-10,72)$ & \\
\hline \multicolumn{5}{|l|}{ Pekerjaan Ibu: } \\
\hline Tidak Bekerja & 15 & 12 & $2,88(0,88$ & 0,048 \\
\hline Bekerja & 10 & 23 & $-9,61)$ & \\
\hline \multicolumn{5}{|l|}{ Uang saku siswi } \\
\hline$<$ Rp.20.000/hari & 10 & 8 & $2,25(0,64$ & 0,153 \\
\hline$>$ Rp.20.000/hari & 15 & 27 & $-8,06)$ & \\
\hline \multicolumn{5}{|l|}{ Penghasilan Orang } \\
\hline \multicolumn{5}{|l|}{ Tua } \\
\hline$<$ Rp.1.3000.000/bulan & 12 & 8 & $3,12(0,90$ & \\
\hline$>$ Rp.1.3000.000/bulan & 13 & 27 & $-11,08)$ & 0,042 \\
\hline \multicolumn{5}{|l|}{ Jumlah Anggota } \\
\hline Keluarga & & & & \\
\hline$>3$ orang & 21 & 13 & $8,88(2,19$ & \\
\hline $1-3$ orang & 4 & 22 & $-39,28)$ & 0,0003 \\
\hline
\end{tabular}

\section{Hubungan Variabel-variabel Independen dengan} Sikap

Tabel 4 menunjukkan bahwa 1) siswi yang bapaknya berpendidikan SD dan SMP berisiko 4,9 kali memiliki sikap negatif tentang IMS dibandingkan siswi yang bapaknya berpendidikan SMA dan PT $(\mathrm{CI} 95 \% ; \mathrm{OR}=1,1-23,5) ; 2)$ siswi yang bapaknya bekerja sebagai buruh dan pedagang berisiko 3,69 kali memiliki sikap negatif tentang IMS dibandingkan siswi yang bapaknya bekerja sebagai pegawai swasta/PNS/TNI (CI95\%; OR=0,94 - k14,96); 3) siswi yang ibunya tidak bekerja berisiko 4,7 kali memiliki sikap negatif tentang IMS dibandingkan siswi yang ibunya bekerja (CI95\%; OR=1,3 - 16,9); 4) siswi yang uang sakunya kurang dari 20.000 rupiah per hari berisiko 6,2 kali memiliki sikap negatif tentang IMS dibandingkan siswi yang uang sakunya lebih dari 20.000 rupiah per hari $(\mathrm{CI} 95 \%$; OR=1,6 -
25,3); 5) siswi yang penghasilan orang tuanya kurang dari 1.300.000 rupiah per bulan berisiko 4,5 kali memiliki sikap negatif tentang IMS dibandingkan siswi yang penghasilan orang tuanya $(\mathrm{CI} 95 \%$; OR $=1,3$ - 16,8); 6) siswi yang jumlah anggota keluarganya lebih dari 3 orang berisiko 4,2 kali memiliki sikap negatif tentang IMS dibandingkan siswi yang jumlah anggota keluarganya 1 - 3 orang $(\mathrm{CI} 95 \%$; $\mathrm{OR}=1,1-$ $16,4)$.

Table 4

Distribusi Hubungan Variabel-variabel Independen dengan Sikap Siswi tentang Penyakit Infeksi Menular Seksual di SMA Uswatun Hasanah Jakarta Timur Tahun 2011

\begin{tabular}{|c|c|c|c|c|}
\hline \multirow{2}{*}{$\begin{array}{c}\text { Variabel } \\
\text { Independen }\end{array}$} & \multicolumn{2}{|c|}{ Sikap } & \multirow[b]{2}{*}{$\begin{array}{c}\text { OR } \\
(95 \% \text { CI })\end{array}$} & \multirow[b]{2}{*}{$\begin{array}{c}\mathbf{P} \\
\text { valu } \\
\mathbf{e}\end{array}$} \\
\hline & $\begin{array}{c}\text { Ne } \\
\text { gati } \\
\text { f }\end{array}$ & $\begin{array}{l}\text { Pos } \\
\text { itif }\end{array}$ & & \\
\hline \multicolumn{5}{|l|}{ Umur siswi } \\
\hline $15-16$ tahun & 9 & 7 & $3,07(0,81-$ & 0,058 \\
\hline $17-18$ tahun & 13 & 31 & $11,84)$ & \\
\hline \multicolumn{5}{|l|}{ Pendidikan } \\
\hline \multicolumn{5}{|l|}{ Bapak } \\
\hline SD dan SMP & 8 & 4 & $4,86(1,07-$ & \\
\hline SMA dan PT & 14 & 34 & $23,45)$ & 0,016 \\
\hline \multicolumn{5}{|l|}{ Pendidikan Ibu } \\
\hline SD dan SMP & 10 & 9 & $2,69(0,76-$ & 0,081 \\
\hline SMA dan PT & 12 & 29 & $9,66)$ & \\
\hline \multicolumn{5}{|l|}{ Pekerjaan } \\
\hline \multicolumn{5}{|l|}{ Bapak: } \\
\hline Buruh//pedagang & 9 & 6 & $3,69(0,94-$ & 0,030 \\
\hline $\begin{array}{l}\text { Swasta/PNS/Polri/ } \\
\text { TNI }\end{array}$ & 13 & 32 & $14,96)$ & \\
\hline \multicolumn{5}{|l|}{ Pekerjaan Ibu: } \\
\hline Tidak Bekerja & 15 & 12 & $4,64(1,32-$ & 0,006 \\
\hline Bekerja & 7 & 26 & $16,95)$ & \\
\hline \multicolumn{5}{|l|}{ Uang saku siswi } \\
\hline$<$ Rp.20.000/hari & 12 & 6 & $6,20(1,60-$ & 0,002 \\
\hline$>$ Rp.20.000/hari & 10 & 31 & $25,29)$ & \\
\hline \multicolumn{5}{|l|}{ Penghasilan } \\
\hline \multicolumn{5}{|l|}{ Orang Tua } \\
\hline $\begin{array}{l}<\text { Rp. } 1.3000 .000 / \mathrm{b} \\
\text { ulan }\end{array}$ & 12 & 8 & $4,50(1,25-$ & 0,008 \\
\hline $\begin{array}{l}>\text { Rp. } 1.3000 .000 / b \\
\text { ulan }\end{array}$ & 10 & 30 & $16,80)$ & \\
\hline \multicolumn{5}{|l|}{ Jumlah Anggota } \\
\hline$>3$ orang & 17 & 17 & $4,20(1,13-$ & 0,014 \\
\hline $1-3$ orang & 5 & 21 & $16,43)$ & \\
\hline
\end{tabular}

\section{Hubungan Pengetahuan dan Sikap}

Tabel 5 menunjukkan bahwa siswi yang pengetahuan tentang IMS nya rendah berisiko 4,3 kali memiliki sikap negatif tentang IMS dibandingkan siswi yang pengetahuan tentang IMS nya tinggi $(\mathrm{CI} 95 \% ; \mathrm{OR}=1,2-15,5)$. 
Tabel 5

Hubungan Pengetahuan dengan Sikap Responden

Tentang Penyakit Infeksi Menular Seksual di SMA Uswatun Hasanah Jakarta Timur Tahun 2011

\begin{tabular}{|c|c|c|c|c|}
\hline \multirow[b]{2}{*}{ Pengetahuan } & \multicolumn{2}{|c|}{ Sikap } & \multirow{2}{*}{$\begin{array}{c}\text { OR } \\
(95 \% \text { CI })\end{array}$} & \multirow{2}{*}{$\begin{array}{c}\mathbf{P} \\
\text { value }\end{array}$} \\
\hline & Negatif & Positif & & \\
\hline Rendah & 14 & 11 & \multirow{2}{*}{$\begin{array}{c}4,30(1,23- \\
15,45)\end{array}$} & \multirow[t]{2}{*}{0,008} \\
\hline Tinggi & 8 & 27 & & \\
\hline
\end{tabular}

\section{PEMBAHASAN}

\section{Kualitas dan Akurasi Data}

Kualitas data ditentukan oleh relevansi data dan vaiditas data, sedangkan akurasi data ditentukan oleh relevansi data, validitas data dan reliabilitas data.

1. Relevansi data adalah sampai dimana data yang terkumpul, diolah dan dianalisis dapat mencapai tujuan khusus. Dalam penelitian ini terdapat relevansi data karena tujuan khusus tercapai dari data yang sudah terkumpul, diolah dan dianalisa.

2. Validitas data terdiri atas validitas eksternal dan validitas internal

a. Validitas eksternal adalah seberapa jauh hasil penelitian dalam sampel dapat digeneralisasikan ke populasi yang lebih luas. Dalam penelitian ini hasil penelitian hanya terbatas peda 60 orang siswi SMA Uswatun Hasanah saja di Jakarta Timur

b. Validitas internal mrupakan oposit dari Error yang terdiri atas systematic error dan random error; 1) Systematic error (bias) terdiri atas bias seleksi, bias informasi dan bias confounding bias. Dalam penelitian ini bias seleksi tidak dapat dihindari, bias informasi mungkin terjadi dan confounding bias tak dapat diketahui karena tidak dilakukan analisis multivariat. 2) Random error yang terdiri atas alpha error dan beta error yang digunakan untuk penentuan besar sampel pada jenis desain tertentu. Dalam penelitian ini yang jenis desainnya secara epidemiologis adalah descriptive cross sectional, namun dilakukan analisis bivariat, tidak ditentukan besar sampel atas dasar alpha error dan beta error itu.

c. Reliabilitas data ialah konsistensi dari hasil pengukuran menurut orang dan waktu. Dalam penelitian ini pengumpulan data hanya dilakukan satu kali, dengan demikian pengukuran juga dilakukan satu kali, jadi reliabilitas data tidak dapat ditentukan. Karena itu disarankan pengumpulan data dilakukan 2 kali sehingga reliabilitas data dapat diukur.
Karena keterbatasan dalam validitas ini, maka untuk penelitian lebih lanjut direkomendasikan supaya diusahakan sampel yang representatif, menghitung besar sampel sesuai dengan jenis desain analytic cross sectional, dan dilakukan analisis multivariat. Walaupun hasil penelitian ini ada keterbatasan dalam arti kualitas dan akurasi data seperti tersebut di atas, masih ada maanfaat yang dapat diambil dari penelitian ini sebagai berikut: Siswi SMA Uswatun Hasanah yang mempunyai pengetahuan rendah tentang IMS adalah $41,73 \%$ dan yang bersikap negatif adalah $36,7 \%$. Dengan demikian secara teoritis dapat dikatakan hal ini mengakibatkan banyaknya terjadi perilaku seksual berisiko pada remaja seperti yang telah dijelaskan dalam latar belakang penelitian ini. Direkomendasikan supaya dilakukan penelitian lebih lanjut untuk mengetahui hubungan antara pengetahuan dan sikap remaja dengan perilaku seksual remaja yang berisiko.

Keterbatasan khusus dari hasil penelitian ini karena besar sampel tidak didasarkan atas jenis desain yang bersangkutan, dan terlihat itu merupakan ukuran sampel yang kecil namun didapat hasil penelitian sebagai berikut: 1) Siswi yang berumur 15-16 tahun, ibunya tak bekerja, penghasilan orang tuanya yang < Rp. 1,300,000 dan jumlah anggota keluarganya $>3$ orang berisiko mempunyai pengetahuan yang rendah tentang IMS; 2) Siswi yang pendidikan bapaknyya hanya SD atau SMP, ibunya tak bekerja, uang hariannya $<20,000$, penghasilan orang tuanya $<\mathrm{Rp}$. $1,300,000$ dan jumlah anggota keluarganya $>3$ orang berisiko ersikap negatif; dan 3) Pengetahuan siswi yang rendah tentang IMS berisiko siswi tersebut bersikap negatif tentang apa yang disebut IMS. Atas dasar hasil penelitian ini namun dengan keterbatasannya, kita bukan mengrekomendasikan, tetapi menyarankan sebagai berikut: 1) Perlu melakukan pendidikan sekas (penyakit IMS) kepada siswi SMA Uswatun Hasanah yang diprioritaskan kepada siswi yang berumur 15-16 tahun yang mungkin Kelas I SMA, dan yang uang saku hariannya $<\mathrm{Rp}$. 20,000; 2) Perlu melakukan komunikasi, memebrikan informasi dan edukasi (KIE) kepada ibu dan bapak siswi SMA Uswatun Hasanah tentang IMS kususnya ibu tak bekerja, yang penddidikan bapaknya hanya SD/SMP, penghasilan keluarganya , Rp. 1,300,000, dan jumlah anggota keluarganya $>3$ rang.

\section{KESIMPULAN}

1. Pengetahuan siswinya yang rendah tentang penyakit IMS adalah $41,7 \%$ dan yang bersikap negatif adalah $36,7 \%$.

2. Siswi yang berumur 15-16 tahun, ibunya tak bekerja, penghasilan orang tuanya $<\mathrm{Rp} 1,300,000$, dan jumlah anggota keluarganya $>3$ orang lebih berisiko mempunyai pengetahuan rendah tentang 
IMS bila dibandingkan dengan siswi yang berumur 17-18 tahun, ibu ya bekerja, penghasilan orang tuanya $>$ Rp. 1, 300,0000 dan jumlah anggota keluarganya $<3$ orang.

3. Siswi yang pendidikan bapaknya SD/SMP, ibunya Tak bekerja, uang saku hariannya $<20,000$, penghasilan orang tuanya $<\mathrm{Rp} .1,300,000$ dan jumlah keluarganya $>3$ orang lebih berisiko mempunyai sikap negatif tentang IMS dibandigkan dengan siswi yang pendidikan bapaknya SMA ke atas, ibunya bekerja, uang saku hariannya $>$ Rp. 20,000 , penghasilan orang tuanya $>$ Rp. 1 , 300,000 , dan jumlah anggota keluarganya $<3$ orang.

4. Pengetahuan siswi tentang IMS yang rendah lebih berisiko mempunyai sikap negatif yang rendah tentang IMS dari pada pengetahuan siswi tentang IMS yang tinggi.

\section{REKOMENDASI DAN SARAN}

1. Rekomendasi: Untuk penelitian lebih lanjut 1) Diusahakan supaya sampel yang representatif, menghitung besar sampel yang sesuai dengan jenis disain analytic cross sectional, dan dilakukan analisis multivariat dan 2) Melakukan penelitian untuk mengetahui hubungan pengetahuan dan sikap remaja tentang IMS dengan perilaku seks berisiko

2. Saran: 1) melakukan pendidikan seks (penyakit IMS) kepada siswa Uswatun Hasanah, yang dippriritaskan kepada siswa yang berumur 15-16 tahun dan yang uang hariannya $<$ Rp.20,000; 2) melakukan komunikasi, memberikan informasi ddan pendidikan (KIE) kepada ibu dan bapak siswi SMA Uchwatul Hasanah kususnya kepada ibu tak bekerja, bapaknya yang berpndidikan SD/SMP, penghasilan keluarga $<$ Rp. 1, 300,000, dan jumlah anggota keluarganya $>3$ orang.

\section{UCAPAN TERIMA KASIH}

Ucapan terima kasih ditujukan kepada Lembaga Penelitian dan Pengembangan UHAMKA yang telah memberi arahan, koreksi, dan dukungan dana sehingga penelitian ini dapat terlaksana. Ucapan terima kasih juga penulis sampaikan kepada Pimpinan FIKES UHAMKA atas arahan dan dukungannya dalam pelaksanaan penelitian dan penulisan artikel ini.

\section{DAFTAR PUSTAKA}

Admin. Artikel dampak dari pergaulan bebas. www. whandi.net. Rabu, 16 April 2008.

Ariawan, Iwan.1998. Besar Dan Metode Sample Pada Penelitian Kesehatan. Depok: Fakultas Kesehatan Masyarakat Universitas Indonesia.
Arief, Irfan. 2008. Remaja dan Hubungan Seksual Pranikah. hhtp://www.pjnhk.go.id, 22 mei 2008.

Asfriyati. 2004. Perilaku Seksual Remaja Santri di Pesantren Purba Baru Tapanuli Selatan Serta Faktor-Faktor Yang mempengaruhinya. Laporan penelitian Dosen Muda. Medan: FKM Universitas Sumatera Utara.

Athar, Shahid. Dr. 2004. Bimbingan seks bagi kaum muda muslim. Jakarta: Pustaka Zahra.

Arikunto, Suharsimi. 1992. Pengelolaan Kelas dan Siswa. Jakarta: Rajawali.

Awaluddin, Latief. 2008. Cerdas Seksual, Sex Education for Teenagers. Bandung: Shofie Media.

BKKBN. 2005. Remaja Memerlukan Informasi Kesehatan Reproduksi, (Online), (http://www.bkkbn.go.id/article detail.php?aid $=325$, diakses 3 Mei 2008).

BKKBN. 2007. Lima dari 100 Siswa SLTA di DKI Berhubungan Seks Sebelum Menikah, (Online), (http://www.bkkbn.go.id/article detail.php?aid $=758$, diakses 3 Mei 2008).

BKKBN. 2006. Tiap Tahun 15 Juta Remaja Melahirkan, (Online), (http://www.bkkbn.go.id/article detail.php?aid $=746$, diakses 3 Mei 2008).

Budiarto, Eko. 2002. Biostatistika untuk Kedokteran dan Kesehatan Masyarakat. Jakarta: EGC.

Chairuna, dkk. 2005. Telaah Pengetahuan, Sikap, dan Perilaku Remaja tentang Kesehatan Reproduksi. Warta Demografi, Tahun 35, No. 1, 18-24.

Chandra, Budiman. 1995. Pengantar Statistik Kesehatan. Jakarta: EGC.

Depkes RI. 2003. Buku Pegangan Fasilitator dan Teknik Penyampaian Materi inti Kesehatan Reproduksi Remaja. Jakarta: Direktorat Jenderal Pembinaan Kesehatan Masyarakat Direktorat Bina kesehatan Keluarga.

Dwikarya, Maria. 2006. Pendidikan Seks untuk Remaja. Jakarta: Kawan Pustaka.

Glasier, Anna. 2006. Keluarga Berencana dan Kesehatan Reproduksi. Jakarta: EGC.

Heru. 2007. Perilaku Seks Remaja di KALSEL Mencemaskan, (Online), (http://www.bkkbn.go.id/article detail.php?aid $=778$, diakses 3 Mei 2008). 
Heru. 2007. 42\% Siswa Cianjur Berhubungan Seks Pra Nikah, (Online), (http://www.bkkbn.go.id/article detail.php?aid $=758$, diakses 3 Mei 2008).

Kartika, Lily Berta. 2005. Survei: Remaja Indonesia Punya Pengalaman Seks Sejak Usia 16. Kompas Cyber Media, (Online). (http://situs.kesrepro.info/krr/feb/ 2005/krr01.htm, diakses 3 Mei 2008).

Kartika, Meylani Diana. 2003. Faktor-Faktor yang Berhubungan dengan Pengetahuan Siswa SMU Putra Bangsa di Depok tentang Kesehatan Reproduksi Remaja Tahun 2003. Depok: FKMUI. Skripsi tidak dipublikasikan.

Kazim, Muhammad Nabil. 2007. Mengelola Masa Puber. Solo: Smart Media.

Makarao, Ramamurti. 1997. Analisis Pengetahuan dan Sikap tentang Kesehatan Reproduksi pada Remaja Kelas 3 SMP Negeri di Cianjur Kota Tahun 1996. Depok: FKMUI. Tesis tidak dipublikasikan.

Maryandi, Dwi Adi. 2005. Faktor-Faktor yang Mempengaruhi Tingkat Pengetahuan Remaja Mengenai Kesehatan Reproduksi Remaja di Drop in Center Cijantung Yayasan Pelita Ilmu tahun 2005. Depok: FKMUI. Skripsi tidak dipublikasikan.

Matsuda, Tommy. 2008. Ajang Ngumpul Remaja Tengtang Kesehatan Reproduksil, (Online), (http://toomymatsuda.wordpress.com/2008/02/ 11 /ajang-ngumpul-remaja-tentang-kesehatanreproduksi/, diakses 3 Mei 2008)

ASW, Maulana. 2007. Kesehatan Reproduksi Remaja Indonesia Memprihatinkan. Interaksi, Tahun IX, No.3, 15.

Mu'tadin, Zainun. 2002. Pendidikan Seksual Pada Remaja. http://www.epsikologi.com/remaja/100702.htm. Minggu, 27 April 2008.

Nathalie, Kollmann. 1998. Kesehatan Reproduksi Remaja. Jakarta: Yayasan lembaga konsumen Indonesia the ford foundation.

Notoatmodjo, Soekidjo. 2002. Metodologi Penelitian Kesehatan. Jakarta: PT Rineka Cipta.
Notoatmodjo, Soekidjo. 2003. Pendidikan dan Perilaku Kesehatan. Jakarta: PT Rineka Cipta.

Praktiknya, Ahmad Watik. 2000. Dasar - Dasar Metodologi Penelitian Kedokteran dan Kesehatan. Jakarta: PT Grafindo Persada.

Sa'abah, Marzuki Umar. 1997. Seks dan Kita. Jakarta: Gema Insani Press.

Santrock, John W. 2003. Adolescence Perkembangan Remaja. Jakarta: Erlangga.

Suryani, Dede. 2003. Faktor- Faktor yang Berhubungan dengan Pengetahuan Remaja SMU 1 Cilaku Kab. Cianjur JABAR tahun 2003. Depok: FKMUI. Skripsi tidak dipublikasikan.

Utama, Sad Widya. 2002. Pengetahuan dan Sikap tentang Kesehatan Reproduksi dan FaktorFaktor yang Mempengaruhinya pada Remaja Kelas 3 SMP di Kec. Karawang Kab. Karawang JABAR 2001. Depok: FKMUI. Tesis tidak dipublikasikan.

Wiliana, Wira . 2003. Faktor-Faktor yang Berhubungan dengan Pengetahuan Kesehatan Reproduksi Remaja, Suatu Studi Kasus di SMUN 5 Bekasi Pondok Gede Jawa Barat 2003. Depok: FKMUI. Skripsi tidak dipublikasikan.

Anak Indonesia Rentan Pengaruh Pornografi, (Online), (http://www. bkkbn.go.id/article detail.php?aid=531, diakses 3 Mei 2008).

. Definisi Kesehatan Reproduksi Remaja, (Online), (http://situs.kesrepro. info/krr/referensi2.htm, diakses 3 Mei 2008).

Perilaku Seks, (Online), (http://situs.kesrepro.info/krr/referensi5.htm, diakses 3 Mei 2008).

PMS dan HIV AIDS, (Online), (http://situs.kesrepro.info/krr/ referensi6.htm, diakses 3 Mei 2008).

Seks, Seksualitas, Kesehatan Seksual, (Online), (http://situs.kesrepro.info /krr/referensi4.htm, diakses 3 Mei 2008).

. Tumbuh Kembang Remaja, (Online), (http://situs.kesrepro.info/krr/ referensi3.htm, diakses 3 Mei 2008). 